\title{
植物油脂をコアとする星型ポリ乳酸の開発
}

\section{辻本 敬・寺田貴彦}

近年，地球規模で環境に対する関心が高まっており，高 分子材料分野に抢いても化石資源の枯渴や地球温暖化の防 止対策からバイオマスの利活用が望まれている。油脂や糖 質は地球上に無尽蔵に存在する水之二酸化炭素加ら合成さ れる再生可能資源であり，これらを原料として利用するこ とは持続可能な材料開発システムの構築に必須なむのとし て期待される。なかであポリ乳酸は款物類を出発物質に得 られるバイオプラスチックであり，力学物性などあ既存の プラスチックに近い性質を示すため, 石油由来プラスチッ クの代替材料として注目されている。しかし，幅広い応用 のためには結晶性が高く，耐衝撃性や耐熱性が低いなどの 課題があり，複合化による物性改善が検討されている1，2。 筆者らはこれまで天然油脂を基盤とする機能性高分子材料 の開発を行ってきだ)。また，ポリ乳酸についても多分岐 型にすることで低融点，低結晶性ポリ乳酸となることを見 いだした。本稿ではヒマシ油をコアとする多分岐型ポリ乳 酸の合成について紹介する。

ヒマシ油はトゥゴマという植物の種子から採取される油 脂であり, 幅広い温度領域で高い流動性を有するため塗料 や化粧品などの工業用原料として利用されている。合成反 応はラクチドと開始剂を任意の割合で混合し，溶融重合に より行った。NMR 測定の結果, ヒマシ油の水酸基に隣接 するメチン由来のピークがシフトしており，七マシ油の水 酸基を開始点に重合が進行していることが確認された。ま た，ラクチドの割合により分子量制御が可能であり，ヒマ シ油の増加に伴い結晶化度が低下しワックス状となること がわかった。ここで測定された分子量は混合比から算出し た值とよく一致しており, 星型ポリ乳酸のみが得られたこ 之が確認された。また，水酸基の数が多いヒマシ油オリゴ マーを開始郕とした場合にはガラス転移温度などに大きな 変化は見られなかったが, 結晶性が著しく低下することが わかった。本結果は星型ポリ乳酸が天然資源のみから構成 されているという利点にとどまらず，ヒマシ油に由来する 流動性によりポリ乳酸の結晶性を抑制しており, ハイン リッド化や樹脂添加剤などへの応用が期待される。筆者ら は反応プロセスの省資源化, 省エネルギー化の観点から未 精製乳酸発醉液を原料としても星型ポリ乳酸の合成に成功 している。

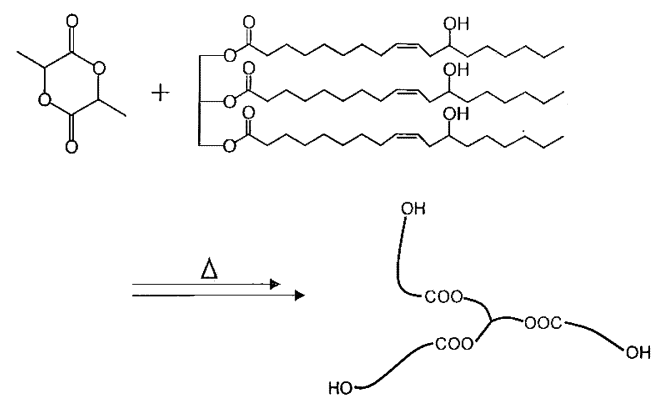

以上で得られた星型ポリ乳酸の応用展開の一つとして末 端水酸基をポリオール源とするウレタン原料があげられ る。これまであヒマシ油はウレタンフォームやウレタン塗 料の合成原料として応用が検討されている4)。星型ポリ乳 酸を用い反応を行ったところ，ヒマシ油単独物を用いた場 合と同様にウレタンフォームが得られた。また，このウレ タンフォームはヒマシ油単独物を用いた場合と比較し, 硬 質であることがわかった。本結果はポリオール源となった 星型ポリ乳酸の構造を変化させることで物性制御が可能で あることを示唆している。

高分子材料分野に扔けるバイオマス原料の利用は物性・ 機能などの問題により, 現状に扔いては限定されていると 言わざるをえない。しかし，バイオプラスチックにおいて も分岐構造などのナノ構造を精密に制御する重合法を開拓 することで溶液・溶融粘度, 融点, および結晶性などのさ まざまな特性制御が可能となる。バイオマス原料のさらな る利活用を促すためにも今後の応用展開が期待される。

\section{文 献}

1) P. Maiti, P. H. Nam, M. Okamoto, N. Hasegawa, A. Usuki: Macromolecules, 35, 2042 (2002)

2) S. Serizawa, K. Inoue, M. Iji: J. Appl. Polym. Sci., 100, 616 (2006)

3) T. Tsujimoto, H. Uyama, S. Kobayashi: Macromol. Rapid Commun., 24, 711 (2003)

4）松永勝治：“最新ポリウレタン材料と応用技術”, CMC, 東京, 2005

Takashi TSUJIMOTO 龍谷大学理工学部物質化学科・助教, 工学博士. 専門は高分子化学.

Takahiko TERADA バイオベース(株)・吥究開発部長. 専門は高分子化学.

Development of Star-Shaped Poly(lactide) with Plant Oil Core 